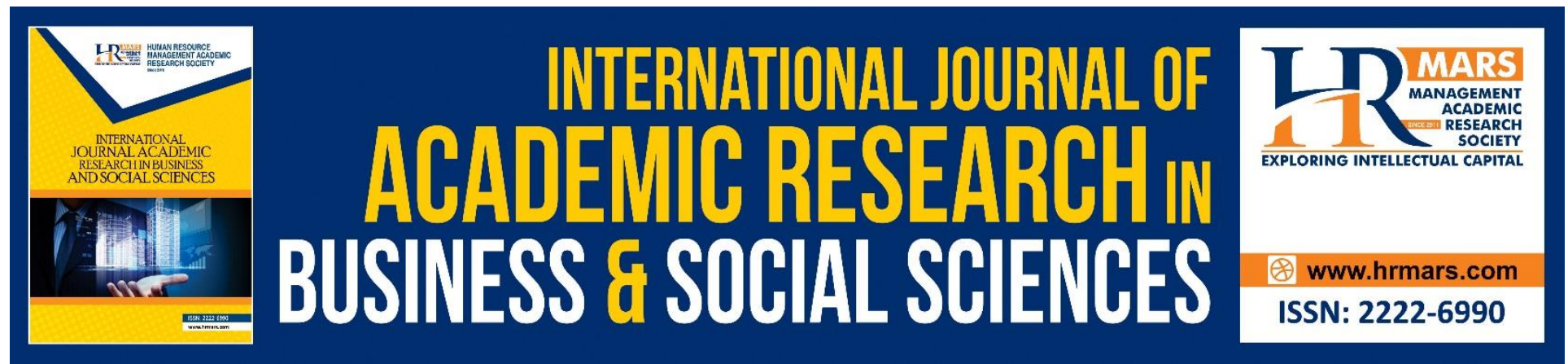

\title{
The Moderating Effect of Sales Skills on Competency and Entrepreneurial Success Co-operative Manager in East Malaysia.
}

Vvy Elvira Pengiran, Stephan L. Sondoh. Jr, Bonaventure Boniface

To Link this Article: http://dx.doi.org/10.6007/IJARBSS/v11-i4/9716

DOI:10.6007/IJARBSS/v11-i4/9716

Received: 05 February 2021, Revised: 08 March 2021, Accepted: 26 March 2021

Published Online: 19 April 2021

In-Text Citation: (Pengiran et al., 2021)

To Cite this Article: Pengiran, V. E., Sondoh, Jr, S. L., \& Boniface, B. (2021). The Moderating Effect of Sales Skills on Competency and Entrepreneurial Success Co-operative Manager in East Malaysia. International Journal of Academic Research in Business and Social Sciences, 11(4), 695-708.

Copyright: () 2021 The Author(s)

Published by Human Resource Management Academic Research Society (www.hrmars.com)

This article is published under the Creative Commons Attribution (CC BY 4.0) license. Anyone may reproduce, distribute, translate and create derivative works of this article (for both commercial and non-commercial purposes), subject to full attribution to the original publication and authors. The full terms of this license may be seen

at: http://creativecommons.org/licences/by/4.0/legalcode

Vol. 11, No. 4, 2021, Pg. 695 - 708

http://hrmars.com/index.php/pages/detail/IJARBSS

JOURNAL HOMEPAGE

Full Terms \& Conditions of access and use can be found at http://hrmars.com/index.php/pages/detail/publication-ethics 


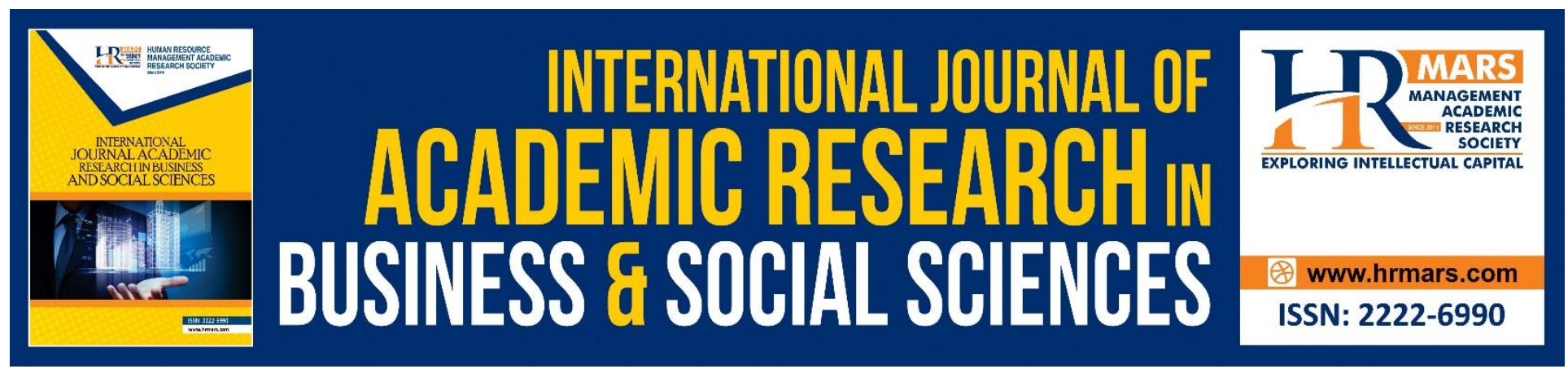

\title{
The Moderating Effect of Sales Skills on Competency and Entrepreneurial Success Co- operative Manager in East Malaysia.
}

\author{
Vvy Elvira Pengiran, Stephan L. Sondoh. Jr, Bonaventure \\ Boniface
}

Faculty of Business, Economic and Accountancy Universiti Malaysia Sabah,

\begin{abstract}
Co-operative is crucial as a catalyst in generating economic development, especially for the poverty reduction among rural population. Despite their importance to the economy, the literature review however indicates that research emphasis on these organizations remains limited and neglected within the local context. This study attempted to investigate the moderating effect of sales skill on competency and entrepreneurial success. The data for the study was collected from 277 co-operatives by using questionnaire. The findings provide guidance for the co-operative to boost its performance in order to transform the nation to be the high financial gain.
\end{abstract}

Keywords: Sales Skills, Competency, Entrepreneurial Success, Co-Operative

\section{Introduction}

In Malaysia the number of cooperative has been increased from 11 co-operatives in 1922, the numbers have grown to 14,417 cooperatives in 2019 with 6,046,031 membership (Cooperative Commission of Malaysia, 2019). Government has played a backbone in supporting economic and the development of cooperative. In order, to help the co-operative sector to significantly contribute toward the state economic process, the government has introduced the National Cooperatives Policy which focusses on accelerating the performance of the co-operatives through the advance within the co-operatives efficiencies in terms of effective management and human capital development, consumer confidence and effective governance (Cooperative Commission of Malaysia, 2019). However, it reported that only several co-operative that has been successful and it the performance of co-operative still low (Idris et al., 2013; Othman, Mansor \& Kari, 2014).

The success of co-operatives lies with their member to manage it (Bond, 2009). Gill and Biger (2012) mention that the competency and skill will brings the successful organization. Successful organizations need inspirational leaders to attain increased and performance. With a talented people and skillful manager, it allow them to perform well. In order to support the cooperative, manager is the person who help the co-operative performance also taking are 
important part in performance of co-operative. They support and strengthen the operation of co-operative to become more effective. It is important to identify the require competencies of manager and understanding competencies and their skill. Hashim and Fawzi (2015) stated that co-operative boards play a major function in linking the managers actions to the interests of their members and customers. Ployhart and Moliterno (2011) stated that to become are successful organization each individual have to possess with knowledge and talents. Therefore, this study will investigate the moderating effect of sales skills on competency and entrepreneurial success co-operative manager in East Malaysia. In order to survive in a dynamic environment manager is required to adapt to changes and continuously improve to meet the needs and expectations of customers. Their capabilities to sales the product will be influence also influence performance. Sales is always a key business skill but, in the current challenging economic climate, it is important that manager to have sales skills especially, adaptive selling and selling skills to have a better understanding and knowledge about their product and customer. These issues have a bearing on the sort of sales skills that are needed in todays rapidly changing commercial world. It is importance for manager to learn to meet the needs of customers. Manager with ability to create relationships with customers and persuade them to make purchases will help the organization successful.

\section{Literature Review}

Gill and Biger (2012) has shown the importance of capability of the person in driving the expansion of organization. In their study, found that need of skills and competency as factors that hinder the expansion of the business success. Rauch and Frese (2007) identify that the competency most correlated with business success. To become successful skills also required for manager to handle their business more practical and efficiency with some business knowledge. They employ their skills and skills to interact with the environment to attain success (Carland, Hoy \& Carland, 1988). Thus, Ployhart and Moliterno (2011) mentioned that the important of human capital theory that predicts individuals or groups who possess greater levels of knowledge, skills, and other competencies will achieve highest performance outcomes than those who has lower levels. According to Yusoff, Jantan and Ibrahim (2004) human capital can be refers as a sort of intellectual capital resulting from the mix of characteristics like knowledge, skills, attitudes, and relationships within the minds, bodies, and actions of people. Human capital are used as theoretical ground for developing arguments that explain manager successful. Based on the literature that indicates substantial competency of manager to become successful. Vidotto, Ferenhof, Selig and Bastos (2017) claims that human capital it is not limited to knowledge and skills but also mentions an individuals actions and attitudes. They also mentioned that it is not enough to only have knowledge and skills; there is a need to put these into practice in the development of organizational activities. Therefore, Linan (2008) highlight important of skills to individual in order that they can manage themselves, become are thinker and acknowledge the business environment. Linan (2008) also mentioned that skills are a part of manager which skills also are put into practice and manifest as a series of knowledge, like skills for adaptation and flexibility and skills for proactivity and negotiation to be success.

Johnston and Marshall (2003) state that the performance of individual effect on personal traits and competency. To become successful skills also required to manager so there can handle their business more effective and efficiency with some business knowledge. Lee and Wong (2004) 
highlight that successful individual have a high desire of independence a primary motive to start and focus their business and they are like to be responsible, decide on strategy, and decide methods working to keep success. Knox (2002) mentioned that it is necessary to organization to adopt and innovative thinking in their decision making in order to achieve customer value. Innovative products may create demand and thus facilitate cooperative growth. In the other hands, Braga, Proenca and Ferreira (2014) stated that individual that able to recognizing opportunity able to grab a challenge and develop idea to be successful. While passion is important to improve individual or entrepreneur ability to enhance their ideas (Elsbach \& Kramer, 2003) and to raise funds from venture capitalists. A strong manager indeed ones of the most critical elements hand in hand co-operative and employee success. Linan (2008) also mentioned that skills are part of manager and that skills are also put into practice and manifest as a series of knowledge, like skills for adaptation and flexibility and skills for proactivity and negotiation in order to be success.

Every successful co-operative has key entrepreneurship that make co-operative well perform. Alstete (2008) claims that being currently involving in entrepreneurship and loving with the present of what they doing which will make them become more independence, freedom and high job satisfaction also can be include as indicates for are entrepreneurial success. Surviving exceeding start-up stage is also an indicator of achieving success (Mitchelmore and Rowley, 2010). Gorgievski, Moriano and Bakker (2014) mentioned that psychological approach also important in asses entrepreneurial success. According to Tregear (2005) that the values of an individual are affiliated to fundamental sources of satisfaction, as well as the perceptions of the intentions of the individual, such as his or her goals and desired results. These values influence the amount of effort and resources that individual will assign to certain business activities in order to achieve success.

\section{Met Hodology and Hypothesis Development}

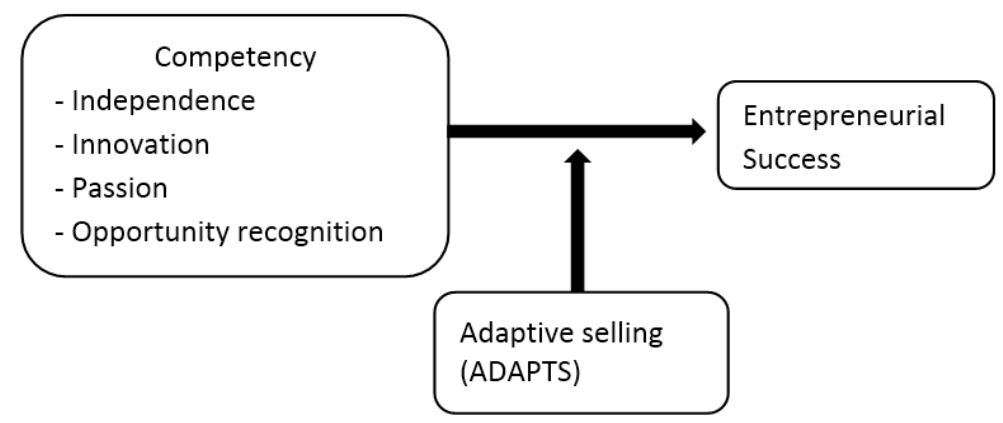

Figure 3.0: The moderating effect of sales skills on competency and entrepreneurial success co-operative manager in East Malaysia.

\section{Independence}

Kirkley (2016) stated that independence as a belief that emerging in individual to let it become motivator of entrepreneurial behavior, explicitly if carried by high levels of confidence or selfefficacy in ones abilities to get things done. Douglas and Fitzsimmons (2013) also pointed out that self-efficacy is correlated to both of entrepreneurial and individual intentions while 
independence is associated to entrepreneurial intentions. Braga et al. (2014) studies also found that independence has correlated significantly to the entrepreneurial motivations. Based on the above statement, it can be say that manager tends to be happy when they can work without any barriers. Manager able to make own independent decision and flexible own their work. Therefore;

H1 : There are positive relationship between independence and entrepreneurial success among co-operative manager in East Malaysia.

\section{Innovation}

Amabile (1988) argues that innovation in a corporation is significantly influenced by the extent of creativity-relevant skills possessed by employees. In addition, creativity from both organization mechanisms and from individuals has a stronger association with innovation performance (Chen \& Yang, 2009). The ideas and the creativity manager will lead to successful results. According to Braga et al. (2014) individual that innovative are able to grab a challenge and develop an idea with are creativity solution. They found that the successful innovator is not significant towards the innovation. Therefore, the manager need to be innovation and be more creative to become success:

H2 : There are positive relationship between innovation and entrepreneurial success among cooperative manager in East Malaysia.

\section{Passion}

Emotions also could be centered on events that are current, desired, past, or future; and passion may be entirely emotional (Chang, 2001), or also may influence and interact with cognitions (Branzei \& Zietsma, 2003; Shepherd, 2003). With passion, manager can faced any difficulty with more persistence. Passion will help manager to think the motive and goal to be success. Ucbasaran, Wright and Westhead (2009) and Westhead and Wright (1998) also stated that entrepreneurs who manifest high levels of passion for founding are entrepreneurs. Thus;

H3 : There are positive relationship between passion and entrepreneurial success among cooperative manager in East Malaysia.

\section{Opportunity Recognition}

According to Corbett (2005) entrepreneurial process specific and different approach learning will be effective. This supported by Dimov (2007) which found that entrepreneurial opportunities more discover based on different learning style and processing experience, based on creation and evaluation. Therefore, Timmons and Spinelli (2007) highlight that opportunities recognition is vital to person who seen entrepreneurship gets continuously renewed through the process of opportunity identification. With a proper time and a good opportunity recognition will lead manager to become successful. Thus;

H4: There are positive relationship between opportunity recognition and entrepreneurial success among cooperative manager in East Malaysia.

\section{Adaptive Selling (ADAPTS)}

Adaptive selling involves tailoring ones own manners to adapt to the selling context, it entails that specialize in customers individual needs and preferences, which can cause a customer 
centered, problem-solving orientation. For example, showing empathy with customers to develop a relationship and to better understand their needs may lead to high customer orientation of the manager. As Spiro and Weitz (1990) founded that ADAPTS are related to performance. Therefore:

H5(a): The positive relationship between independence and entrepreneurial success will be stronger when adaptive selling skill is high.

H5(b): The positive relationship between innovation and entrepreneurial success will be stronger when adaptive selling skill is high.

H5(c): The positive relationship between passion and entrepreneurial success will be stronger when adaptive selling skill is high.

$H 5(d)$ : The positive relationship between opportunity recognition and entrepreneurial success will be stronger when adaptive selling skill is high.

\section{Result and Analysis}

Specifically, the main purpose of using quantitative research is to test the hypotheses that reflect the current situation. A self-administered form was developed using structured questions. The target population of this study is cooperative manager and establish more than five years, Ahmad and Seet (2009) stated that in the five years begin organization in Malaysia the failure rate is high rise at 60 percent. PLS analysis will be employed in this study with initial stage for investigating the reflective measurement of the model assessment. It is important to ensure the reliability and validity of the variables to complete the assessment of the structural model (Wong, 2013).

Majority of respondents are (78.3\%) are male and only $60(21.7 \%)$ of respondent were female. Most respondents in this cooperative are aged around 41 to 50 years old more than 90 respondents which is 35.7 percent, followed by 51 years old and above 85 respondents which is at 30.7 percent. Aged around 31 to 40 years old 58 respondents which is 20.9 percent and least numbers respondent is from 21 years old to 30 years old which is only 12.6 percent for about 35 respondents. Based on the result working experience in cooperative from respondent only 3.2 percent have one year experience is for nine respondents. Majority respondents have one year to five years experiences which is contribute 70.4 percent for 195 respondents. Six to ten years 18.8 percent which is contribute by 52 respondents and respondents have experience more than 10 years contribute 7.6 percent from 21 respondents. Table below shown the measurement model analysis for this study. 
INTERNATIONAL JOURNAL OF ACADEMIC RESEARCH IN BUSINESS AND SOCIAL SCIENCES

Vol. 11, No. 4, 2021, E-ISSN: 2222-6990 @ 2021 HRMARS

Model Analysis

Table 1 Measurement Model Analysis

Construct Item Loading Composite Average

Reliability Variance

Extracted

(AVE)

\begin{tabular}{|c|c|c|c|c|}
\hline Adapt & AS1 & 0.888 & 0.903 & 0.701 \\
\hline & AS2 & 0.876 & & \\
\hline & AS3 & 0.844 & & \\
\hline & AS4 & 0.73 & & \\
\hline \multirow[t]{4}{*}{ Inno } & IN1 & 0.724 & 0.821 & 0.537 \\
\hline & IN2 & 0.834 & & \\
\hline & IN3 & 0.744 & & \\
\hline & IN4 & 0.613 & & \\
\hline \multirow[t]{4}{*}{ Indep } & IP1 & 0.735 & 0.804 & 0.511 \\
\hline & IP2 & 0.784 & & \\
\hline & IP3 & 0.784 & & \\
\hline & IP4 & 0.525 & & \\
\hline \multirow[t]{4}{*}{ Oppor } & OP1 & 0.798 & 0.86 & 0.607 \\
\hline & OP2 & 0.711 & & \\
\hline & OP3 & 0.831 & & \\
\hline & OP4 & 0.77 & & \\
\hline \multirow[t]{4}{*}{ Passion } & P1 & 0.784 & 0.872 & 0.631 \\
\hline & P2 & 0.787 & & \\
\hline & P3 & 0.838 & & \\
\hline & P4 & 0.766 & & \\
\hline \multirow[t]{6}{*}{ Success } & SF1 & 0.564 & 0.865 & 0.521 \\
\hline & SF3 & 0.744 & & \\
\hline & SF4 & 0.806 & & \\
\hline & SF5 & 0.724 & & \\
\hline & SF6 & 0.798 & & \\
\hline & SF7 & 0.665 & & \\
\hline
\end{tabular}

Fornell and Larker Criterion analysis was presented in table 4.2 below. In this analysis the Discriminant Validity in value by using the cross loading and calculate the square root of the difference the average taken ( $\mathrm{AVE}$ ) for each of the constructs. Square root of the difference the average taken ( $V \mathrm{AVE}$ ) to all factors must be greater than all correlation between the constructs and other constructs. From the table of figure below shows all values correlation is lower than the power source AVE (V AVE). 
INTERNATIONAL JOURNAL OF ACADEMIC RESEARCH IN BUSINESS AND SOCIAL SCIENCES

Vol. 11, No. 4, 2021, E-ISSN: 2222-6990 @ 2021 HRMARS

Table 2 Fornell and Larker Criterion

\begin{tabular}{lrrrrr}
\hline Construct & 1 & 2 & 3 & 4 & 5 \\
\hline Adap & $\mathbf{0 . 8 3 7}$ & & & & \\
Indep & 0.38 & $\mathbf{0 . 7 1 5}$ & & & \\
Inno & 0.492 & 0.627 & $\mathbf{0 . 7 3 3}$ & & \\
Passion & 0.366 & 0.518 & 0.462 & $\mathbf{0 . 7 9 4}$ & \\
Success & 0.275 & 0.315 & 0.357 & 0.532 & $\mathbf{0 . 7 2 1}$ \\
\hline
\end{tabular}

The Assessment of Significance and Relevance of the Structural Model Relationship

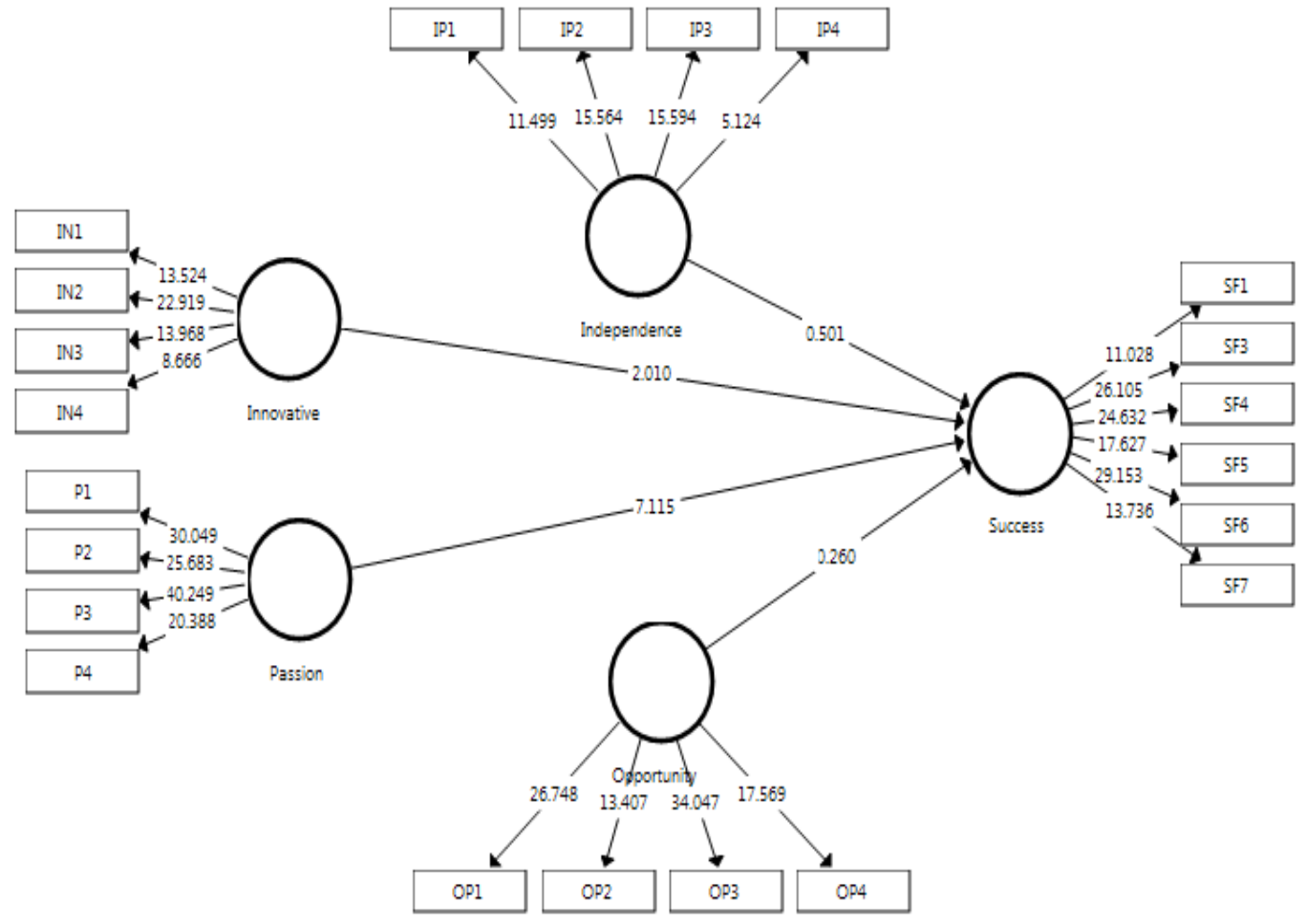

Figure 2 Structural Model Bootstrap

Measuring the formative indicator assesses the significance and relevance of the formative indicators. This can be done by bootstrapping. According to Hair et al. (2013), the bootstrapping result might be significant. If the formative indicator are not significant, the researcher can retain the indicator based on content validity.

\section{Moderator Analysis}

In this study, the test of significant independent variables to the dependent variable effected with bootstrapping t-statistics are used to find out if the relationship between variables positive or significant supported or not supported, i.e. equivalent to a significant $\mathrm{p}<0.01(\mathrm{t}=2.33 * *)$ and $\mathrm{p}<0.05\left(\mathrm{t}=1.645^{*}\right)$. Based on the result only $\mathrm{H} 5 \mathrm{~b}$ was significant with $\mathrm{t}$-value of 2.11 [LLCl= $0.025, \mathrm{ULCl}=0.224]$. Hence, $\mathrm{H} 5 \mathrm{~b}$ is supported. Meanwhile $\mathrm{H} 5 \mathrm{a}$ with $\mathrm{t}$-value of 0.745 [LLCl= -0.178 , $\mathrm{ULCl}=0.62], \mathrm{H} 5 \mathrm{c}$ with $\mathrm{t}$ value of $0.394[\mathrm{LLCl}=-0.123, \mathrm{ULCl}=0.188]$ and $\mathrm{H} 5 \mathrm{~d}$ with $\mathrm{t}$ value of 1.613 
INTERNATIONAL JOURNAL OF ACADEMIC RESEARCH IN BUSINESS AND SOCIAL SCIENCES Vol. 11, No. 4, 2021, E-ISSN: 2222-6990 @ 2021 HRMARS

$[\mathrm{LLCl}=-0.278, \mathrm{ULCl}=-0.010]$ are not significant .

\section{Moderator Adaptive Algorithm}

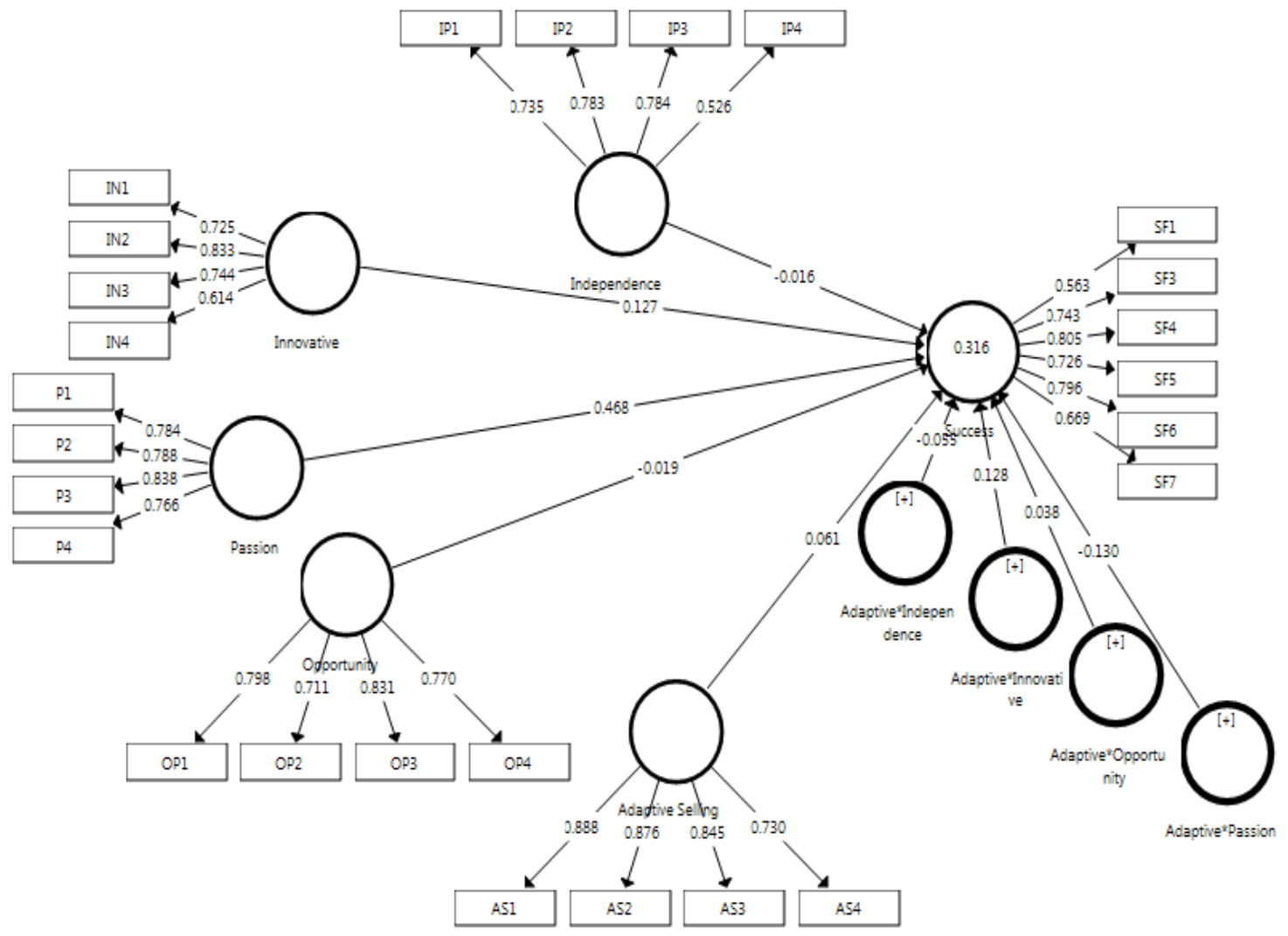

Figure 3 Adaptive Algorithm 


\section{Bootstrapping Adaptive}

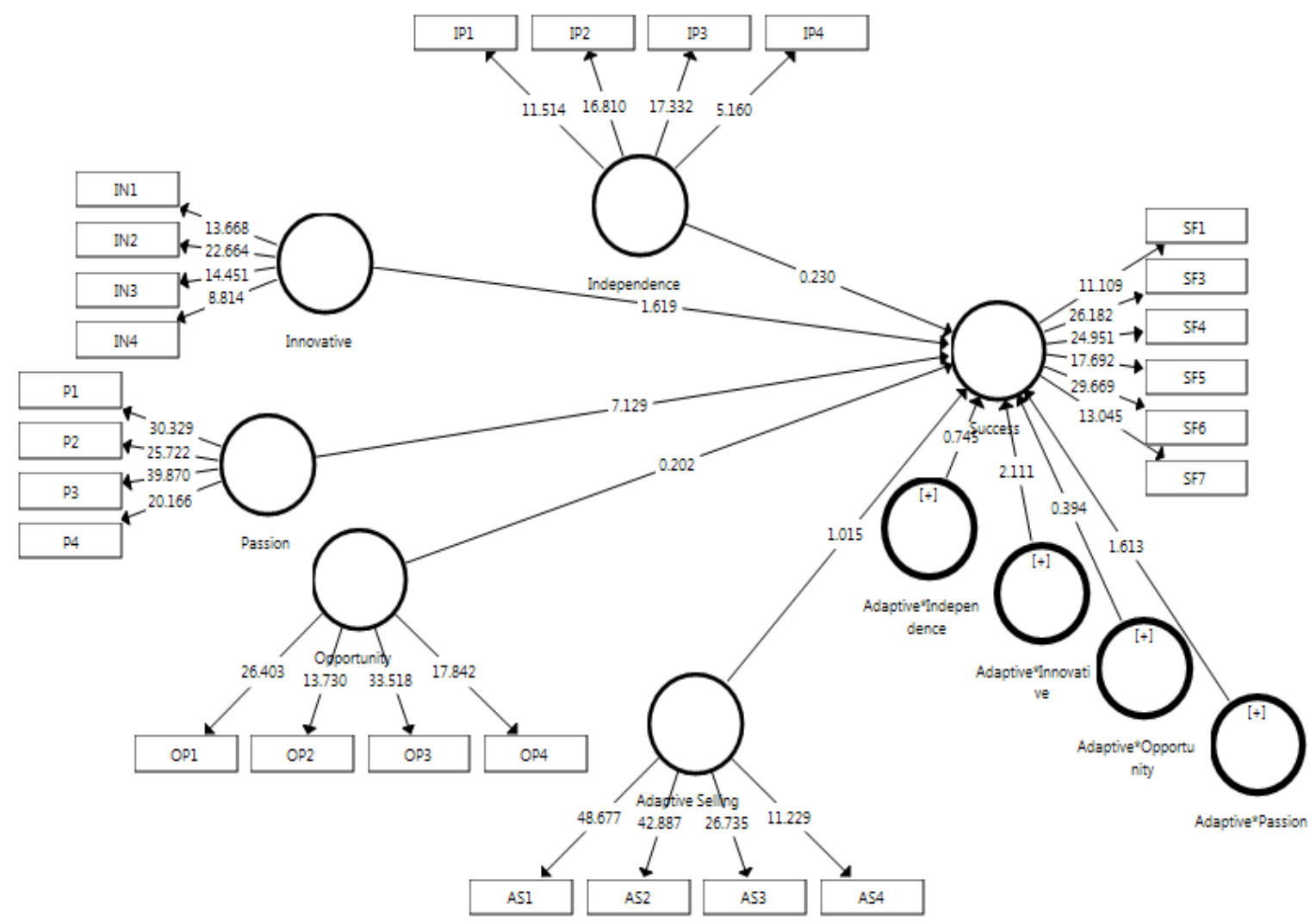

Figure 4. Bootstrapping Adaptive

\section{Interpreting interaction effects}

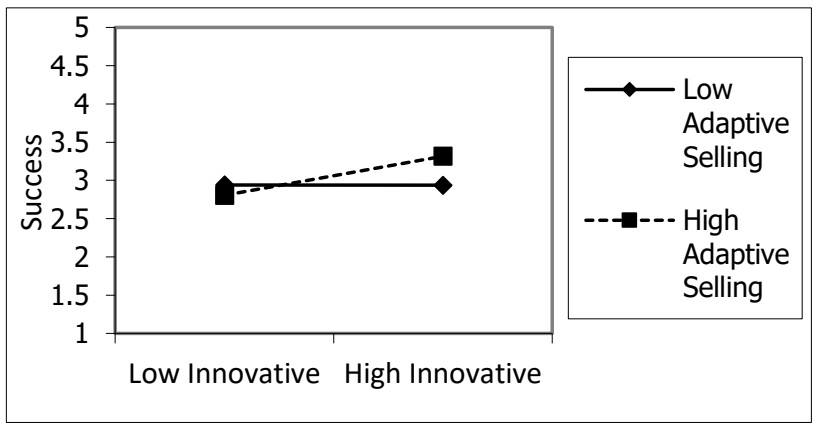

\begin{tabular}{|l|r|}
\hline \multicolumn{2}{|l|}{ Variable names: } \\
\hline $\begin{array}{l}\text { Name of independent } \\
\text { variable: }\end{array}$ & Innovation \\
\hline Name of moderator: & Adaptive Selling \\
\hline \multicolumn{2}{|l|}{ Unstandardised Regression Coefficients: } \\
\hline Independent variable: & 0.127 \\
\hline Moderator: & 0.061 \\
\hline Interaction: & 0.128 \\
\hline Intercept / Constant: & 3 \\
\hline
\end{tabular}

Adaptive selling was examined as a moderator between innovation and entrepreneurial success. Innovation and entrepreneurial success were entered and the regression coefficients for innovation is 0.127 , adaptive selling 0.061 , interaction is 0.128 and intercept is $=3$. 
INTERNATIONAL JOURNAL OF ACADEMIC RESEARCH IN BUSINESS AND SOCIAL SCIENCES

Vol. 11, No. 4, 2021, E-ISSN: 2222-6990 @ 2021 HRMARS

\section{Results of Hypothesis Testing}

The summary of hypothesis testing stated in table below.

\begin{tabular}{|c|c|c|c|}
\hline Hypothesis & Relationship & & Result \\
\hline $\mathrm{H} 1$ & Independence -> Success & $\begin{array}{l}\text { Independence will be positively related to entrepreneurial } \\
\text { success. }\end{array}$ & Not Supported \\
\hline $\mathrm{H} 2$ & Innovation -> Success & Innovation will be positively related to entrepreneurial success & Supported \\
\hline H3 & Opportunity -> Success & $\begin{array}{l}\text { Opportunity recognition will be positively related to } \\
\text { entrepreneurial success. }\end{array}$ & Not Supported \\
\hline $\mathrm{H} 4$ & $\begin{array}{l}\text { Passion -> Success } \\
\text { Moderator }\end{array}$ & Passion will be positively related to entrepreneurial success. & Supported \\
\hline $\mathrm{H} 5 \mathrm{a}$ & $\begin{array}{l}\text { Adaptive*Independence -> } \\
\text { Success }\end{array}$ & $\begin{array}{l}\text { The positive relationship between independence and } \\
\text { entrepreneurial success will be stronger when adaptive selling skill } \\
\text { is high. }\end{array}$ & Not Supported \\
\hline $\mathrm{H} 5 \mathrm{~b}$ & $\begin{array}{l}\text { Adaptive*Innovation -> } \\
\text { Success }\end{array}$ & $\begin{array}{l}\text { The positive relationship between innovation and entrepreneurial } \\
\text { success will be stronger when adaptive selling skill is high. }\end{array}$ & Supported \\
\hline $\mathrm{H} 5 \mathrm{c}$ & $\begin{array}{l}\text { Adaptive*Opportunity -> } \\
\text { Success }\end{array}$ & $\begin{array}{l}\text { The positive relationship between opportunity recognition and } \\
\text { entrepreneurial success will be stronger when adaptive selling skill } \\
\text { is high. }\end{array}$ & Not Supported \\
\hline $\mathrm{H} 5 \mathrm{~d}$ & Adaptive*Passion $->$ Success & $\begin{array}{l}\text { The positive relationship between passion and entrepreneurial } \\
\text { success will be stronger when adaptive selling skill is high. }\end{array}$ & Not Supported \\
\hline
\end{tabular}




\section{Discussion}

Based on the result showed significant relationship positive between innovation to entrepreneurial success $(\beta=0.146, t=2.01)$. Schumpeter $(1942)$ innovation has been associated with entrepreneurial success, growth and profit. According to Braga et al. (2014) innovative individual will do things differently and it shows that innovation has a positive related become success. This shows that innovations are related to entrepreneurial success as well creativity will help the ideas towards manager. Innovative and creativity will create positive impact towards company. Other than that, passion also found positively related to entrepreneurial success. $\mathrm{H} 4 \quad(\beta=0.469, \mathrm{t}=7.115)$ was found positively related to entrepreneurial success. Passion is an emotion that comes from within enthusiasm, passion, drive and motivation Cardon et al. (2005). Passion will make individuals have desire to become a more entrepreneurial. Braga et al. (2014) found that which are passion is most factors for individual to sustain in the business. The results shows that adaptive selling and innovation is moderated by enterpreneurial success. $\mathrm{H} 5 \mathrm{~b}$ was significant with $\mathrm{t}$-value of 2.11 $[\mathrm{LLCl}=0.025, \mathrm{ULCl}=0.224]$. Plouffe et al. (2009) mentioned that successful individual readily acknowledge that variety approaches for fulfill customer need and wants. Generally, to enhance the performance outcomes, manager need to have adaptive selling strategy and innovation to become entrepreneurial success.

\section{Conclusion}

In conclusion, this study has successfully assessed the moderating effect of sales skills on competency and entrepreneurial success among co-operative manager in Sabah and Sarawak. In the case of Sabah and Sarawak, passion and innovation influence entrepreneurial success among the manager in East Malaysia. In addition with adaptive selling enhance entrepreneurial success within the co-operative. Recognizing the important competency and skill is important to enhance the performance of co-operative. In terms, of managerial implications, the findings of the study are beneficial to co-operatives organization. This study will contribution to our understanding of the performance and also the characteristics of co-operatives that are successful across various sizes and functions. In an exceedingly broader context, this study could provide valuable input to the regulatory, the board members and also the managers involved within the management of cooperatives because the findings would provide them the background to evaluate the performance of individual co-operative.

Studying co-operatives will assist in differentiating between entrepreneurial and nonentrepreneurial manager which may lack the knowledge and experience in not only entrepreneurship but also strategic management as well as business activities that may have limited impact not only on the co-operatives but also the economy. Correspondingly, identification to better factors could assist co-operative to focus their efforts on building the necessary capacity and competency to achieve success. There some limitation of this study, the response rate for participants to answer the questionnaire is low. The survey conducted during this research take an extended time to urge response from participant to answer the questionnaire. The response rate for participants to answer the questionnaire is low. For the future research, this study suggested to cover Peninsular Malaysia as well to know the more dynamic of co-operative. Researcher also suggested to using mixed method to gain in breadth and depth of understanding on the issues. 


\section{Corresponding Author}

Stephan L. Sondoh. Jr

Faculty of Business, Economic and Accountancy Universiti Malaysia Sabah

Email: jude@ums.edu.com

\section{References}

Ahmad, N. H., \& Seet, P. (2009). Dissecting Behaviours Associated with Business Failure: A Qualitative Study of SME Owners in Malaysia and Australia. Journal of Asian Social Science, 5 (9), 98-104.

Amabile, T. M. (1988) A Model of Creativity and Innovation in Organizations. Research in Organizational Behavior, 10, 123-167.

Alstete, J. (2008). Aspects of entrepreneurial success. Journal of Small Business and Enterprise Development, 15(3), 584-594.

Arulrajah, A. A., Opatha, H. H. D. N. P., \& Nawaratne, N. N. J. (2015). Green Human Resource Management Practices: A Review, Sri Lankan Journal of Human Resource Management, 5(1), $1-16$.

Braga J. C., Proenca, T., \& Ferreira, M. R. (2014). Motivations for social entrepreneurshipevidences from Protugal. Tekhne- Review of applied management Studies, 12, 11-21.

Branzei, O., \& Zietsma, C. (2003). Entrepreneurial love: The enabling functions of positive illusions in venturing, Paper presented at the Babson-Kauffman Entrepreneurial Research Conference, Wellesley, MA.

Bond, J. K. (2009). Cooperative Financial Performance and Board of Director Characteristics: A quantitative investigation, Journal of Cooperatives, 22, 22-44.

Carland, J. W., Hoy, F., \& Carland, J. A. C. (1988). Who is an entrepreneur? is a question worthasking, American Journal of Small Business, Spring, 33-9.

Chang, R. (2001). Turning passion into organizational performance. Training and Development, 55(5), 104-112.

Chen, M. H., \& Yang, J. Y. (2009). Typology and performance of new ventures in Taiwan. International Journal of Entrepreneurial Behavior \& Research, 15(5), 398- 414.

Corbett, A. C. (2005). Experiential learning within the process of opportunity identification and exploitation. Entrepreneurship Theory and Practice, 29(4), 473-491.

Dimov, D. (2007) Beyond the single person, single insight attribution in understanding entrepreneurial opportunities, Entrepreneurship Theory and Practice, 31(5), 713-731.

Douglas, E. J., Fitzsimmons, J. R. (2013). Intrapreneurial intentions versus entrepreneurial intentions: distinct constructs with different antecedents, Small Business Economics, 41, 15- 132.

Elsbach, K. D., \& R. M. Kramer. (2003). Assessing creativity in Hollywood pitch meetings: Evidence for a dual-process model of creativity judgments. Academy of Management Journal, 46: 283-301.

Gill, A., \& Biger, N. (2012) Barriers to small business growth in Canada. Journal of Small Business and Enterprise Development, 19(4), 656-668.

Gorgievski, M. J., Moriano, J. A., \& Bakker, A. B. (2014) Relating work engagement and workaholism to entrepreneurial performance. Journal of Managerial Psychology, 29, 106-121.

Hashim, M. K., \& Fawzi, D. K. (2015) Issues, Scope and Focus of Research on Cooperatives in Malaysia. Journal of Education and Social Sciences, 2, (Oct.) 
Idris, W. S. R., Yacob, Y., Abdullah, F. M., Motadza, M. S., Morshidi, M. H. (2013), Faktor-faktor kritikal kejayaan perniagaan kedai runcit di koperasi di negeri Sarawak. Malaysian Journal of Co-operative Studies 9, 93-114.

Kirkley W.W. (2016). Entrepreneurial behaviour: the role of values, International Journal of Entrepreneurial Behavior \& Research, 22(3), 290-328.

Knox, S. (2002). The boardroom agenda: developing the innovative organization, Corporate Governance, 2(1), 27-39.

Lee, S. H., \& Wong, P.K. (2004). An exploratory study of technopreneurial intentions: a career anchor perspective. Journal of Business Venturing, 19(1), 7-28.

Linan, F. (2008). Skill and value perceptions: how do they affect entrepreneurial intentions?. International Entrepreneurship and Management Journal, 4(3), 257-272.

Marshall, G. W., Goebel, D. J., \& Moncrief, W. C. (2003). Hiring for success at the buyer-seller interface. Journal of Business Research, 56(4), 247-255.

Mitchelmore, S., \& Rowley, J. (2010). Entrepreneurial competencies: a literature review and development agenda. International Journal of Entrepreneurial Behaviour \& Research, $16(2), 92-111$.

Othman, A., Mansor, N., \& Kari, F. (2014). Assessing the performance of co-operatives in Malaysia: an analysis of co-operative groups using a data envelopment analysis approach, Asia Pacific Business Review, 20(3), 484-505.

Ployhart, R. E., and Moliterno, T. P (2011). Emergence of the human capital resource: A multilevel model. Academy of Management Review, 36,127-150.

Puhakka, V. (2011). Developing a creative-cognitive model of entrepreneurial alertness to business opportunities. Journal of Management and Strategy, 2(4), 85.

Rauch, A., \& Frese, M. (2007). Lets put the person back into entrepreneurship research: A metaanalysis on the relationship between business owners personality traits, business creation and success. European Journal of Work \& Organizational Psychology, 16, 353385.

Spiro, R. L., Weitz, B. A. (1990). Adaptive selling: Conceptualization, measurement, and nomological validity. JMR, Journal of Marketing Research, 27(1), 61-69.

Tregear, A. (2005). Lifestyle, growth, or community involvement? The balance of goals of UK artisan food producers. Entrepreneurship \& Regional Development, 17(1), 1-15.

Timmons, A. J., Spinelli, S. (2007). New Venture Creation: Entrepreneurship for the 21st Century, 7th ed., Chapter 1, McGraw-Hill, NY. 2007.

Ucbasaran, D., Westhead, P., and Wright, M. (2009). The extent and nature of opportunity identification by experienced entrepreneurs, Journal of Business Venturing, 24, 99-115.

Vidotto, J. D. F., Ferenhof, H. A., Selig, P. M., Bastos, R. C. (2017). A human capital measurement scale. Journal of Intellectual Capital, 18, 316-329.

Westhead, P., Wright, M. (1998). Novice, portfolio and serial founders: Are they different? Journal of Business Venturing 13 (3), 173-204.

Wong, K. K. K. (2013). Partial least squares structural equation modeling (PLS-SEM) techniques using SmartPLS. Marketing Bulletin, 24(1), 1-32.

Yusoff, W. F. W., Jantan, M., \& Ibrahim, D. N. (2004). The interactive effects of human capital, structural capital and social capital on firm performance, Asian Academy of Management Journal, 9(2), 1-18. 